\title{
Does overshoot in leaf development of ponderosa pine in wet years leads to bark beetle outbreaks on fine-textured soils in drier years?
}

\author{
Wendy Peterman ${ }^{1 *}$ and Richard $\mathrm{H}$ Waring ${ }^{2}$
}

\begin{abstract}
Background: Frequent outbreaks of insects and diseases have been recorded in the native forests of western North America during the last few decades, but the distribution of these outbreaks has been far from uniform. In some cases, recent climatic variations may explain some of this spatial variation along with the presence of expansive forests composed of dense, older trees. Forest managers and policy makers would benefit if areas especially prone to disturbance could be recognized so that mitigating actions could be taken.

Methods: We use two ponderosa pine-dominated sites in western Montana, U.S.A. to apply a modeling approach that couples information acquired via remote sensing, soil surveys, and local weather stations to assess where bark beetle outbreaks might first occur and why. Although there was a general downward trend in precipitation for both sites over the period between 1998 and 2010 (slope $=-1.3, R^{2}=0.08$ ), interannual variability was high. Some years showed large increases followed by sharp decreases. Both sites had similar topography and fire histories, but bark beetle activity occurred earlier (circa 2000 to 2001) and more severely on one site than on the other. The initial canopy density of the two sites was also similar, with leaf area indices ranging between $1.7-2.0 \mathrm{~m}^{2} ? \mathrm{~m}^{-2}$. We wondered if the difference in bark beetle activity was related to soils that were higher in clay content at site I than at site II. To assess this possibility, we applied a process-based stand growth model (3-PG) to analyze the data and evaluate the hypotheses.

Results: We found that when wet years were followed by drier years, the simulated annual wood production per unit of leaf area, a measure of tree vigor, dropped below a critical threshold on site I but not on site II.

Conclusion: We concluded that the difference in vulnerability of the two stands to beetle outbreaks can be explained largely by differences in gross photosynthesis attributed to the fact that an equivalent amount of stored water in the rooting zone $(100 \mathrm{~mm})$ is extracted less efficiently from fine-textured soils than from coarse-textured ones.
\end{abstract}

\section{Background}

In the past few decades, world-wide forest decline has been reported in association with increases in temperature and decreases in precipitation (Allen et al. 2010). Throughout forests in western North America the extent of disturbances caused by fire, insects and diseases is unprecedented (Raffa et al. 2008; Bentz et al. 2009). Drought reduces tree defenses, enabling insects to surpass a population threshold required for an outbreak (Berg et al. 2006; Rouault et al. 2006).

\footnotetext{
* Correspondence: wendy@consbio.org

${ }^{1}$ Conservation Biology Institute, 136 SW Washington Ave, Ste 202, Corvallis, OR 97333, USA

Full list of author information is available at the end of the article
}

The impact of biotic agents is, however, expected to be spatially patchy (Dale et al. 2001; Allen et al. 2010). Density-dependent processes between the host organism and its attackers differ with local variations in soils and topography as well as with the physiological status of the host trees (Christiansen et al. 1987; Allen et al. 2010). Satellite-derived records of disturbance confirm that tree mortality is not uniformly distributed and that some of the variation can be attributed to differences in soil (Yoshiko and Mueller-Dombois 1995; Brasier 1996; Turner and Lambert 2005; Bigler et al. 2006; Hogg et al. 2008; Harper et al. 2009). In general, outbreaks are more prevalent on poorer quality sites and where there are large populations of overly-dense, older trees (Fettig et al. 2007). 
Furthermore, the mechanism by which beetles recognize, attack, and kill trees is well-described (Horntvedt et al. 1983; Christiansen et al. 1987; Franceschi et al. 2005). Beetles bore into the phloem of the trees, creating tunnels in the secondary phloem and deposit their eggs, simultaneously allowing the entry of mutualistic fungi, which can disrupt the vascular system of the trees with their hyphae, leading to tree morality (Horntvedt et al. 1983; Franceschi et al. 2005; Raffa et al. 2008). In healthy trees, a rapid flush of resin expels the initial beetle attack (Erbilgin et al. 2003), and a barrier of dead or hardened tissue forms around the fungal infection to prevent it from spreading (Horntvedt et al. 1983).

Because the beetles have co-evolved with their host tree species, they have developed mechanisms for overcoming tree defenses (Franceschi et al. 2005). It is widely accepted that aggressive beetle species overwhelm the trees physiological abilities to produce defensive tissues and chemicals by recruiting threshold numbers of individuals (Christiansen 1985; Wallin and Raffa 2000, 2004; Huber et al. 2004; Franceschi et al. 2005). Production of bark, resin ducts and toxins is very energetically costly and dependent on trees ability to partition resources from local storage and photosynthesis to defense systems (Bryant and Julkunen-Tiitto 1995; Franceschi et al. 2005). The ability to create defensive mechanisms is compromised by water stress, temperature stress and pollution (Franceschi et al. 2005; Raffa et al. 2008).

Since the start of the 21st century, there are many places in the western United States where long-term patterns in precipitation have changed from past conditions (Allen et al. 2010). The northern Rocky Mountain region is one of those places, as mapped by Waring et al. (2011). In western Montana, outbreaks of bark beetles on ponderosa pine (Pinus ponderosa) have been reported at lower elevations, but the pattern is not uniform (USFS FHTET 2010). Such spatial variation in tree mortality raises a number of questions. Are trees more stressed on shallow soils than deeper soils in the region? Does soil texture play a role in drought stress for these trees? Is tree vigor somehow affected by interannual variations in precipitation? We hypothesize that 1) if tree photosynthesis is more constrained for trees growing on high clay soils than low clay soils under similar climate conditions, then beetle activity will be greater on clayey sites in dry years than on non-clayey sites, and 2) if there is an imbalance in interannual variations in leaf to stem growth ratios, then tree vigor will drop below threshold values for trees to become vulnerable to beetle attacks.

\section{Methods}

\section{Approach}

We can discern climatic trends from published records and obtain maps of soil properties for areas in western
Montana. It is difficult, however, to obtain ground measurements of plant water stress retrospectively or to assess subtle changes in canopy leaf area. Some researchers have correlated climatic variation from tree ring analyses (Garfinkel and Brubaker 1980; Briffa et al. 1990; Villalba 1990) and from the analysis of variations in the stable isotopes of carbon (Panek and Waring 1997). These types of analyses are spatially restricted and require a non-random approach to defining areas for sampling. In this paper, we propose an alternative approach by utilizing a processbased stand growth model driven by climatic variables that also incorporates important soil properties. Such models simulate the dynamics of trees as they shift their growth between leaves, stems and roots in response to seasonal and annual climatic and soil conditions.

In a stable environment, a forest canopy can be expected to reach a maximum leaf area index (LAI) that can be supported by available soil moisture and fertility (Waring 1983). In western coniferous forests, LAI varies from $<1$ to $12 \mathrm{~m}^{2}$ ? $\mathrm{m}^{-2}$ (Runyon et al. 1994; Waring et al. 2014). If growing conditions become less favorable, the LAI will decrease, often abruptly (Pook 1984), which can result in increased tree mortality. Field experiments (Christiansen et al. 1987) have shown that the ratio of annual wood production to LAI, termed growth efficiency (GE), has proven useful as a general index of tree vigor and specifically to identifying the vulnerability of pine stands to attacks from mountain pine beetles (Dendroctonus ponderosae) (Coops et al. 2009).

We chose to use the 3-PG process-based growth model (Physiological Principles Predicting Growth) to simulate forest responses to differences in the climate and soil conditions that affect tree vigor and forest vulnerability to disturbances such as bark beetles. Process-based growth models use mathematical representations of biotic and abiotic processes to simulate components of both the water and carbon balances. 3-PG is widely used to represent the multiple interactions between climate, soils and forests with its main focus on predicting growth as measured by foresters (i.e. tree number, mean diameter, basal area, volume, with thinning and defoliation subroutines).

\section{Study areas}

Using PRISM climate data in a geographic information system (GIS) environment, we selected two study sites in western Montana where climate conditions are consistent, but there have been uneven distributions of bark beetle activity. The area selected lies within the Lewis and Clark National Forest (Latitude: 47.1833? N, Longitude: 111.4500? W) and extends over an elevation range of $1400 \mathrm{~m}$ to $2900 \mathrm{~m}$. The vegetation in the region is a mixture of evergreen conifers, subalpine fir (Abies lasiocarpa), Douglas-fir (Pseudotsuga menziesii), lodgepole pine (Pinus contorta), Englemann spruce (Picea engelmannii), and ponderosa pine (Pinus 
ponderosa). The climate is continental with minimum winter temperatures dropping to -12 ? $\mathrm{C}$ and summer maximums reaching 24?C. Precipitation averages between 90 and $100 \mathrm{~cm}$ ? $\mathrm{yr}^{-1}$ with more in the spring than summer or winter. Both sites selected are classified as wilderness and are not used for timber production. Sixty-four percent of the ponderosa pine forest is considered highly stocked and susceptible to disease and insect attack (DeBlander 2002). For our research, we selected a 24-year period between 1998 to 2010, when two major outbreaks of mountain pine beetle (Dendroctonus ponderosae) occurred, one circa 2001 to 2004, the other circa 2006 to 2010.

We chose two sites where beetle outbreaks were recorded and mapped by the USFS aerial surveys (Figure 1). The presence of ponderosa pines at these locations was verified using Forest Inventory and Analysis (FIA) plots and Littles tree range maps. A meteorological station was situated near site I at an elevation of $1844 \mathrm{~m}$, where the mortality of ponderosa pine averaged 750 trees?ha $^{-1}$ the first year of the beetle outbreak one circa 2001 and 950 trees?ha ${ }^{-1}$ at the beginning of the second outbreak circa 2007. Another meteorological station, located at an elevation of $2469 \mathrm{~m}$, was near site II, where tree mortality was 400 trees?ha $^{-1}$ circa 2001 and 1300 trees?ha $^{-1}$ circa 2007. Forest canopies at both sites were fairly open with maximum leaf area indices ranging between 1.7 to $2.0 \mathrm{~m}^{2} ? \mathrm{~m}^{-2}$. The boundaries around site II were irregular in shape to include the full range of elevations at which ponderosa pine was recorded and where soil survey data were available. The dominant soils on site I are Mollisols, Entisols, Inceptisols and Vertisols developed on carbonate, alluvium and fine to medium-grained sedimentary and clastic parent materials. On site II, the dominant soils are Mollisols, Inceptisols, Alfisols and Entisols formed on carbonate, quartzite and coarse-grained volcanic parent materials.

\section{Climatic conditions}

Monthly meteorological data for local weather stations (Crystal Lake and Spur Park, MT) for the years 1985 to 2013 were downloaded in tabular format from the

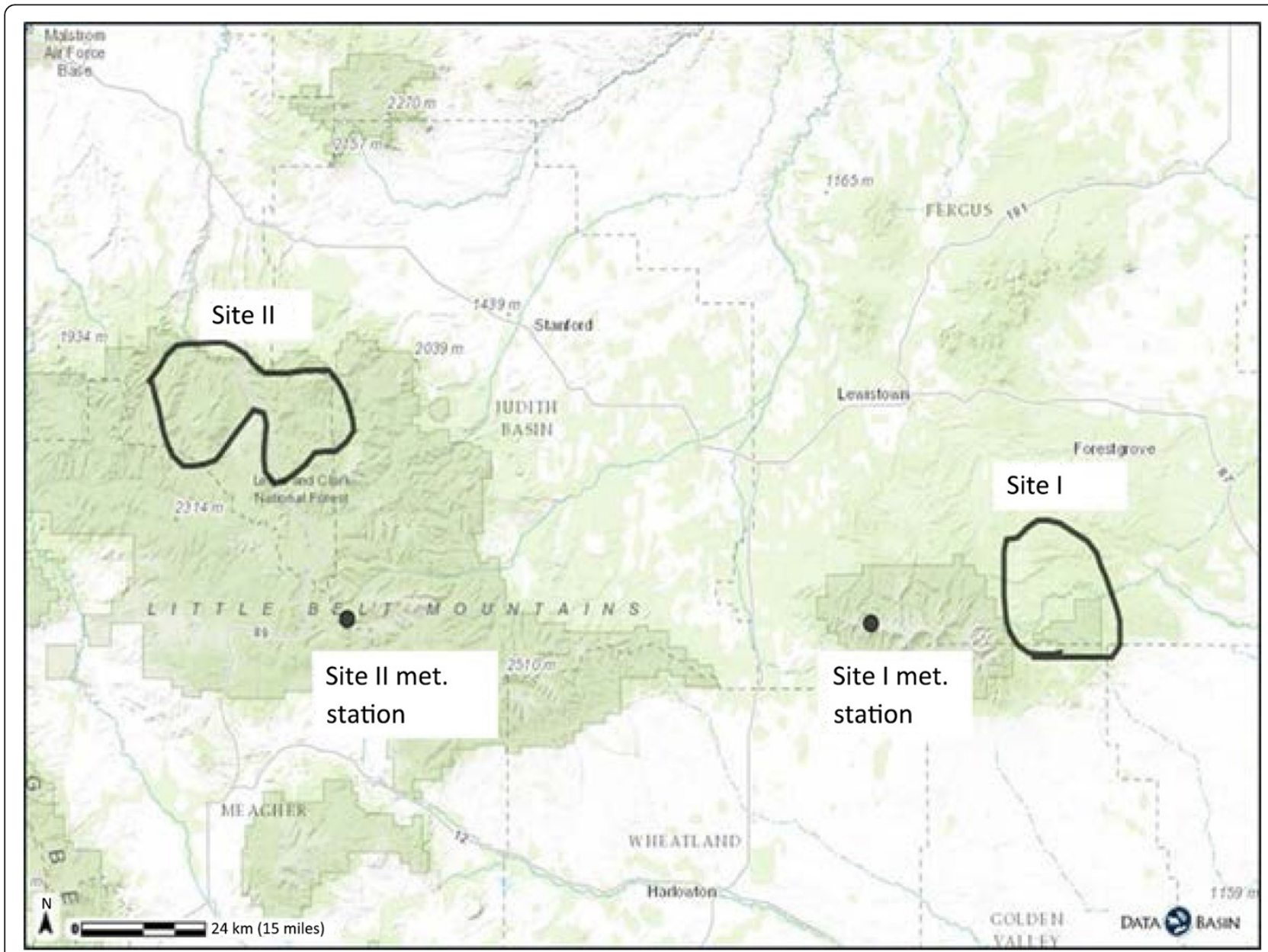

Figure 1 Study sites. Map showing two study sites in western Montana with black dots showing locations of meteorological stations used for climate data. 
National Oceanic and Atmospheric Administration (NOAA) Climate Data Online website (NOAA and 2013). Some missing values and errors in the temperature and precipitation tables were filled using correlations with the station at Lewistown, MT and the first-order automated surface observation station (ASOS) at the Helena, MT airport (Additional file 1). Since solar radiation data were not available for these sites, we calculated monthly mean values, using differences between temperature extremes following procedures outlined by Coops et al. (2000). At each site, the correlation between calculated averaged solar radiation for each month of the year and that measured at Helena, MT was 0.99 (Additional file 1). Similarly, the evaporative demand, expressed as mean day-time vapor pressure deficit (VPD) each month and the number of frost days $(<-2$ ?C) were calculated from monthly mean temperature extremes using the 3-PG function tools (3PGpjs version 2.7, 3-PG version 1, September 2010).

\section{GIS analysis}

In addition to climate conditions, soil characteristics such as water storage capacity, fertility and texture are well known to limit forest productivity (Viereck et al. 1983; Powers et al. 2005; Xu et al. 2008; Puhlick et al. 2012). Initial comparisons of forest mortality for all tree species in western Montana and soil characteristics were made by intersecting polygons in the Soil Survey Geographic database (SSURGO) soil data (NRCS 2014; min. 1:24000) with polygons in the annual forest die-off data (USFS FHTET, min. 1:100000) from 1998 to 2010 to join the attributes from the soil map unit polygons to the tree mortality polygons. The US Forest Service (USFS) aerial surveys combined low-level flights (315 to $630 \mathrm{~m}$ above ground level) and US Geological Survey paper maps (1:100000 scale), as well as a digital sketchmap system (GPS and GIS database) to record the area of disturbance on an annual basis. Due to the size of the polygons and the patchy nature of forest insect activity, some polygons may have contained unaffected areas. For the sake of recording new damage, only trees with yellow, brown or red foliage or some defoliation were mapped as part of the aerial survey. Dead trees with no foliage were assumed to be recorded in a previous years study. Soil mapping units were aggregated to generalize common properties and to minimize differences associated with variable spatial scales. Tree mortality data was summarized by percent of the area of dead trees and compared to the percent of the area where tree cover was greater than 50\% (Fry et al. 2011) and no mortality was recorded during the time period. To refine this study to specific sites and a specific tree species, soil characteristics between two areas in Montana were then compared to seek possible differences among ponderosa pine forests where tree mortality was recorded between 1998 and 2010. GIS analysis was performed by overlaying datasets representing ponderosa pines killed by mountain pine beetles at the two sites between 1998 and 2010 (Meddens et al. 2012) along with SSURGO soils data.

\section{Remote sensing}

Landsat graphs of monthly greenness (NDVI) values for the years 1998 to 2010 were downloaded from the Glovis Data Viewer (Tile IDs: LT50380271998231PAC00, path 38, row 27, product: ETM + L1T and LT50390271999193XXX02 path 39, row 27, product: ETM + L1T) (USGS 2014). These were used to compare trends in the normalized difference vegetation indices (NDVI) (Eq. 1) for both sites and to calculate estimates for maximum annual leaf area index $\left(\mathrm{LAI}_{\max }\right)$. Estimates were made from a correlation established between NDVI and LAI reported by Turner et al. (1999):

$\begin{array}{lccc}\text { NDVI } & 0.5724 & 0.0989 \mathrm{LAI}- & 0.0114 \mathrm{LAI}^{2} \\ & & 0.0004 \mathrm{LAI}^{3}, R^{2} & 0.74\end{array}$

This method was chosen due to the similarity in the range of NDVI and LAI values between their sites and ours. Additionally, the testing of their correlations over a broad range of temperate sites using Landsat 5 surface reflectance data with atmospheric correction gave us confidence that it would be applicable in our study area.

\section{3-PG process model}

The 3-PG model uses monthly averages of climatic variables to calculate a water balance, carbon budget and energy balance that is summed for the year. At a minimum, precipitation and maximum and minimum air temperature must be provided from meteorological stations. Other climate variables can be calculated using the 3-PG function tools and verified using correlations with nearby weather station records. Four soil variables are also included in the model: minimum and maximum available soil water storage capacity (ASW) in the top $1500 \mathrm{~mm}$ of soil, soil fertility (FR) and soil texture. The soil receives a fraction of the precipitation for each month, and the soil water that is not released through evapotranspiration is added to the next months water balance or allowed to run off (Landsberg and Waring 1997; Waring et al. 2014). ASW is defined as the difference between field capacity (soil moisture held at $1 / 3$ bar tension) and wilting point (soil moisture held at 15 bar tension). FR in the model is a rating on a scale of 0 to 1 , with 0 being the lowest and 1 being the highest. For this study, we fixed the photosynthetic capacity at 0.05 mol C per mol photon (2.75 $\mathrm{gC}^{\mathrm{M}} \mathrm{M}^{-1}$ of absorbed photosynthetically-active radiation). This value has been measured and used in other ponderosa pine growth 
modeling exercises (Waring et al. 2014), and sensitivity analysis of the model showed that lower photosynthetic capacity settings required unrealistically high FR rankings. In the model, photosynthesis is restricted by frost, high vapor pressure deficit, suboptimal temperatures and soil water deficits. Each month, the upper limits on gross photosynthesis are set by the amount of light (PAR) absorbed by the LAI. Approximately half the total gross photosynthesis is assumed to be lost through plant respiration, and the rest is available for growth. Growth is partitioned above- and below-ground as a function of soil fertility and to a lesser extent, soil water deficit (Landsberg and Waring 1997).

\section{Model parameterization and assumptions}

For this modeling exercise, we used the Excel version of 3PG with growth parameters for ponderosa pine based on available literature and Landsat-derived LAI (Table 1). The model parameters can be set to accommodate selected silvicultural treatments such as thinning and fertilization, but these options were not used here. Sensitivity analyses for three soil variables, maximum ASW, FR and soil texture were performed by running the model with two soil variables held constant while the third was changed incrementally. Annual outputs for gross photosynthesis or gross primary productivity (GPP), LAI and Penman-Monteith transpiration were compared to evaluate the effects of each soil variable on key physiological responses. Once realistic values for soil parameters and LAI were determined through GIS, remote sensing and sensitivity analyses, soil texture, FR and ASW were set at values that constrained simulated LAI to the estimated maximum value (1.7 to 2.0 $\left.\mathrm{m}^{2} ? \mathrm{~m}^{-2}\right)$. Model output was compared at annual intervals to interpret the simulated effects of climatic variation on stand growth and water balances for each site.

It was assumed for this exercise that ponderosa pines attacked by bark beetles were more than 60 years old (Coops et al. 2009) and that stand densities exceeded $18 \mathrm{~m}^{2}$ ?ha ${ }^{-1}$ (Schmid and Mata 1992, 2005; Negr?n and Popp 2004), a threshold above which ponderosa pine stands in the Rocky Mountains have been shown to be highly susceptible to beetle attacks (Negr?n and Popp 2004; Zausen et al. 2005). These values were collected from the literature, because local resources only stated that ponderosa pines on the study sites were of ages and densities that made them susceptible to bark beetle attacks (DeBlander 2002).

\section{Results}

\section{Climate data trends}

Warmer, drier trends in climate over the twenty-four year period of this study signaled that atmospheric conditions were becoming more conducive to forest vulnerability to water stress and disturbances (Figure 2). Temperature trends were upward on both sites, with warmer conditions recorded near site I than site II (Figure 2A). Monthly precipitation, when averaged for each year, showed a slight decrease over the twenty-four year period from 1989 to 2013 (Figure 2B).

\section{Soil sensitivity analysis for evaluating soil parameters to constrain LAI}

The relative influence of soil water storage, soil fertility, and soil texture varied in their effects on GPP at the two sites. On both sites, values of ASW $\leq 100 \mathrm{~mm}$ caused a reduction in simulated productivity in years with below average precipitation (Additional file 1). Likewise on both sites, modeled increases in soil fertility (FR) caused an increase in GPP, resulting in the production of more leaf area, but as FR approached 0.5, the relative effects of increasing FR decreased. During periods of lower precipitation, the modeled difference in FR effect was less (Additional file 1). The influence of soil texture on modeled tree growth was most evident on site I, particularly between the years 20012005 and 20062009 (Figure 3).

\section{GIS analysis of soil characteristics and forest mortality areas} Initial GIS analysis of all tree species in western Montana compared to soil texture class showed that $99 \%$ of the area with mortality between 1998 and 2010 had clayey soils, while $94 \%$ of the area with no mortality had loam to sandy loam soils (Figure 4), and 5\% of the area of tree persistence was on clayey soils. Furthermore, GIS analysis of soil characteristics on the two sites in Montana showed that soil water storage capacities varied considerably across the landscape. Most soils in the region could store between 50 and $150 \mathrm{~mm}$ of water. Sand content was generally higher on site II, but the main difference between the soils was the clay content. Clay content on site I ranged between $22 \%$ and $60 \%$, with $80 \%$ of the total area containing soils with between $27 \%$ to $37 \%$ clay content. The clay content of soils at site II was between 0 and $28 \%$, and for $90 \%$ of the area, it was $18 \%$ to $25 \%$. A graph of clay content versus the percent of the area of trees killed by mountain pine beetles showed a close relationship between the area affected and the clay content of the soil (Figure 5). The percent of the total area of beetle-killed trees on soils with $>20 \%$ clay content was approximately $94 \%$ on site I and $65 \%$ on site II.

\section{Modeled results}

Inter-annual variation in simulated LAI showed large increases corresponding with wetter periods and decreases during drier periods (Figure 6). On site I, there was a higher LAI between 2003 and 2006, followed by a reduction in LAI circa 2007 to 2010 (not including the thinning attributed to beetle-caused mortality). On site II, simulated LAI steadily increased between 2000 and 2005 to a peak of $1.8 \mathrm{~m}^{2} ? \mathrm{~m}^{-2}$ and then decreased between 2005 and 2010 . 
Table 1 Summary of parameter settings used in the 3-PG simulations for ponderosa pine

\begin{tabular}{lll}
\hline 3-PG Parameter & Units & $\begin{array}{l}\text { Ponderosa } \\
\text { pine }\end{array}$ \\
\hline
\end{tabular}

Biomass partitioning and turnover

Allometric relationships \& partitioning

Foliage: stem partitioning ratio @ $D=2 \mathrm{~cm}$

Foliage: stem partitioning ratio @ $D=20 \mathrm{~cm}$

Constant in the stem mass v. diam.

0.0046

relationship

Power in the stem mass $v$. diam. relationship

Maximum fraction of NPP to roots

Minimum fraction of NPP to roots

\section{Litterfall \& root turnover}

Maximum litterfall rate

1 ? month $^{-1} \quad 0.021$

Litterfall rate at $t=0$

1 ? $^{\text {month }}{ }^{-1} \quad 0.001$

Age at which litterfall rate has median value

Average monthly root turnover rate months

36

1 ?month $^{-1} \quad 0.015$

NPP \& conductance modifiers

Temperature modifier (fT)

Minimum temperature for growth

Optimum temperature for growth

Maximum temperature for growth

Frost modifier (fFRost)

Days production lost per frost day

Soil water modifier (fSW)

Moisture ratio deficit for $f_{\mathrm{q}}=0.5$

Power of moisture ratio deficit

Canopy structure and processes

Specific leaf area

Specific leaf area at age 0

$\mathrm{m}^{2} ? \mathrm{~kg}^{-1} \quad 3.1$

Specific leaf area for mature leaves

Age at which specific leaf area $=$

$\left(\mathrm{SLA}_{0}+\mathrm{SLA} \mathrm{A}_{1}\right) / 2$

\section{Light interception}

Extinction coefficient for absorption of PAR by canopy

Age at canopy cover

Years

Maximum proportion of rainfall evaporated from canopy

LAl for maximum rainfall interception

Production and respiration

Canopy photosynthetic capacity

$\mathrm{mol}$ C?mol $\quad 0.05$

$\mathrm{PAR}^{-1}$

Ratio NPP/GPP
Table 1 Summary of parameter settings used in the 3-PG simulations for ponderosa pine (Continued)

\begin{tabular}{lll}
\hline Conductance & & \\
Minimum canopy conductance & $\mathrm{m} ? \mathrm{~s}^{-1}$ & 0 \\
Maximum canopy conductance & $\mathrm{m} ? \mathrm{~s}^{-1}$ & 0.016 \\
LAl for maximum canopy conductance & & 5 \\
Defines stomatal response to VPD & $1 ? \mathrm{mBar}{ }^{-1}$ & 0.05 \\
Canopy boundary layer conductance & ${\mathrm{m} ? \mathrm{~s}^{-1}}$ & 0.14 \\
\hline
\end{tabular}

Figure 7 shows growth efficiency (GE = stem growth/ LAI ? 100), normalized over the entire modeled time period. On site I, modeled GE was $10 \%$ below average during outbreak one, and it was approximately $25 \%$ below average during outbreak two. Between outbreaks, however, GE was approximately $20 \%$ above average. On site II, modeled GE was above average preceding outbreak one, at which point it dropped to the average, and then went above average until outbreak two, when it dropped to approximately $15 \%$ below the average. Another difference between the two graphs was that the variance of GE on site I was 0.014 , and on site II, it was 0.008 , reflecting larger departures from the mean on site I.

\section{Discussion}

\section{Simulated sensitivity of ponderosa pine growth to soil} and climate

In the sensitivity analysis, simulated effects of soil texture on GPP were evident on both sites at the end of the study period, but the importance of soil texture was particularly pronounced on site I between 2001 to 2005 and 2006 to 2009. Therefore, it may be that the amount of rain or snowmelt that actually reached the available root-zone water supply during drier periods was lower at site I than site II, because of differences in percolation rates between coarse and fine-textured soils. Water in coarse soils is acted upon only by gravitational forces, and therefore it travels easily through the soil profile and is readily extracted by tree roots (Hacke et al. 2000). Conversely, water in clayey soils is held by capillary forces of cohesion and adhesion, which make drainage to deeper soil layers slower and uptake by tree roots more difficult. We propose that when there is adequate precipitation to allow deep drainage, trees can survive on clayey soils, however, in periods of lower precipitation, there may not be enough water reaching the rooting zone to meet the evaporative demand. Wu and Chen (2013) showed that inter-annual decreases in soil moisture had more influence on forest productivity than did increased summer temperatures, and Nambiar and Sands (1992) showed that the high bulk density and the increased tension per unit of water extracted from clayey soils limited transpiration. Our modeling exercise 
suggests that even with the same available soil water storage capacity, coarse-textured soils provide less constraint on simulated GPP and tree growth than fine-textured soils.

In ponderosa pine ecosystems, soil texture is an important factor in forest water stress during lower precipitation years and post-disturbance regeneration (Scianna 2011). Other ecologists have observed greater pine productivity on coarse-textured soils than fine-textured soils (Franklin and Dyrness 1969; Hoffman and Alexander 1976), and presettlement ponderosa pine growth was more dense on coarse-textured soils (Covington and Moore, 1994). Puhlick et al. (2012) showed that the survival of ponderosa pine seedlings in the southwestern USA was highly dependent on soil texture and parent material. In basalt-derived soils, the water available for ponderosa pine use becomes limited at a moisture content of 10\% (Heidmann and King 1992), whereas in coarse-textured soils, developed from sedimentary rocks, water is not limiting to ponderosa pines until it reaches $1.5 \%$ moisture content.
Simulated effects of interannual variations in precipitation An interesting result of this study is the simulated response of trees to the inter-annual variations in precipitation. In the simulations, the trees added foliage and increased LAI during the years with above-average precipitation. Could this response potentially have adverse consequences if the following year or multiple years have below-average precipitation, and stem growth is unable to meet the evaporative demand of the foliage? Samuelson et al. (2004) showed a lag effect in the response of foliage to large changes in precipitation by correlating current growth of loblolly pine (Pinus taeda) with the previous year s LAI, and Sperry et al. (2002) explained how combinations of soil texture and xylem can impose hydraulic limits on the ability of the foliage to maintain adequate pressure potentials to support a continuous water column. In our simulations, when precipitation fell below average, the trees quickly shed foliage to adapt to the drier conditions, and tree vigor was negatively affected by the sudden drop in leaf area as indicated by the decrease in the following years GE (ratio of change

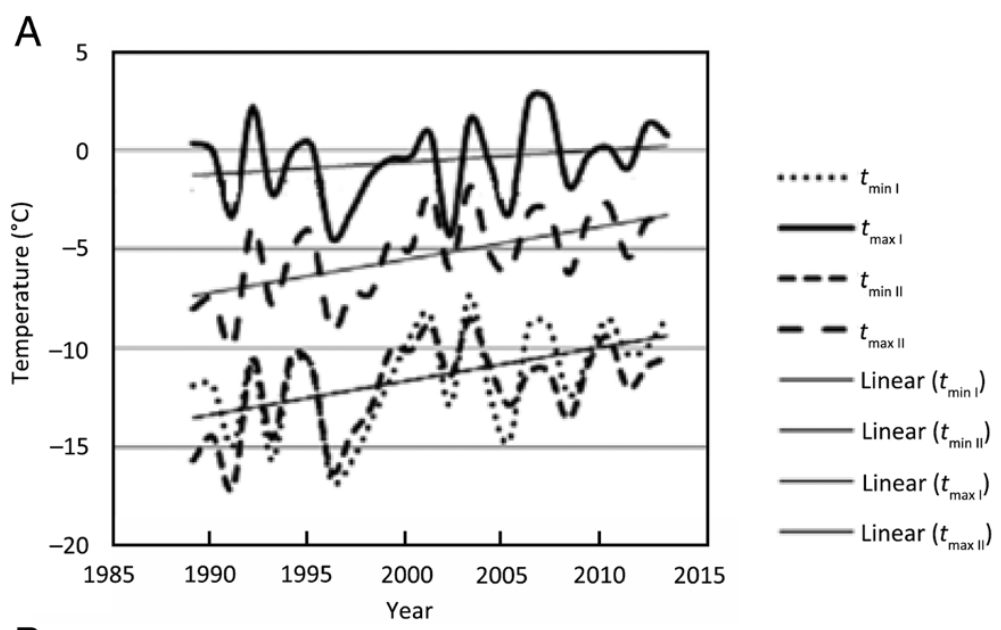

B
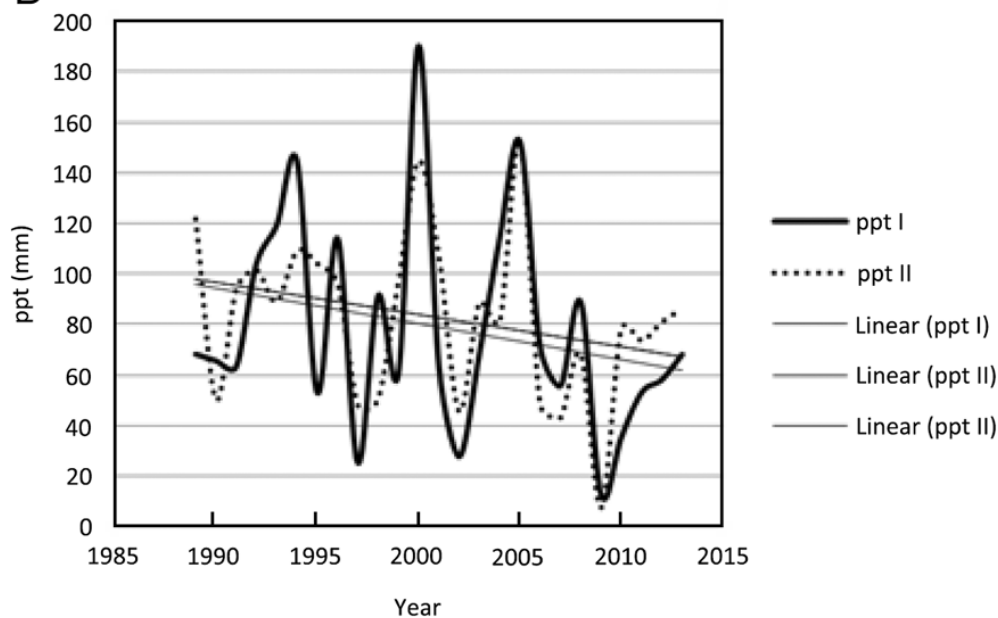

Figure $\mathbf{2}$ Climate trends. Average annual minimum and maximum (A) temperatures and (B) precipitation for site I and site II between the years 1985 and 2013. 


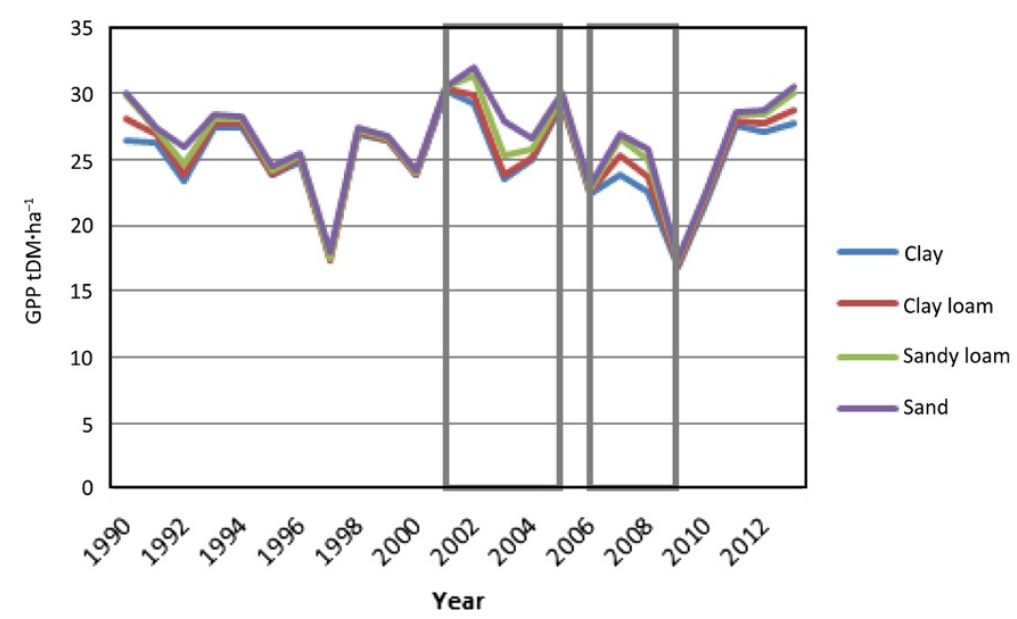

Figure 3 Modeled gross photosynthesis with four different soil textures. Changes greater than 10\% are considered significant. In this graph, the difference between sand and clay is 14.3\% between 2001 and 2005 and 11.5\% between 2006 and 2009. Gray boxes highlight the periods of greater influence of soil texture.

in the change in LAI to stem diameter). Wright et al. (1979, 1984) reported that severe decreases in foliage can make forests more vulnerable to disease. Furthermore, previous studies have shown when GE drops below a threshold level, tree resistance to disease is greatly compromised (Larsson et al. 1983; Waring and Pitman 1983). In this study, simulated GE did not drop below average during outbreak 1 on site II, but it did drop below average prior to outbreak 2 . On site I, however, simulated GE dropped below average prior to both outbreaks. The drop in GE below average signals a decrease in tree vigor and a possible imbalance between stem growth and leaf area. This is not conclusive evidence of an overshoot in leaf development that stressed the trees in drier years but it does give some support to that hypothesis that an imbalance in leaf to stem growth ratios reduces tree vigor, making trees more vulnerable to disturbance. Tree ring and carbon isotope analysis of a sample of trees on the study sites would give measurable data for evaluating this question, which would be a good field study to follow this modeling exercise.

\section{Data and model limitations}

All data are subject to human error and limitations on their ability to accurately and realistically represent nature, based on the spatial scale and precision of measurements taken. According to the USDA NRCS, Soil Survey Division Staff (1995), the US General soil map (STATSGO) is made by generalizing more detailed maps and is not suitable for local planning or productivity analyses. Semi-detailed maps like SSURGO, are based on field measurements, aerial photography and visual inspection of landscape features. They are considered suitable for determining differences and similarities in the soil characteristics of land areas greater than approximately 1 ha and can be used for planning on the level of farms and forests. They are also recommended for use in modeling with other environmental datasets representing geology, vegetation, elevation and climate. SSURGO soil maps are not meant to be used in place of onsite sampling for specific locations and uses. Soils grouped into one map unit will have a great deal of variation in reality, and land use practices will alter soil

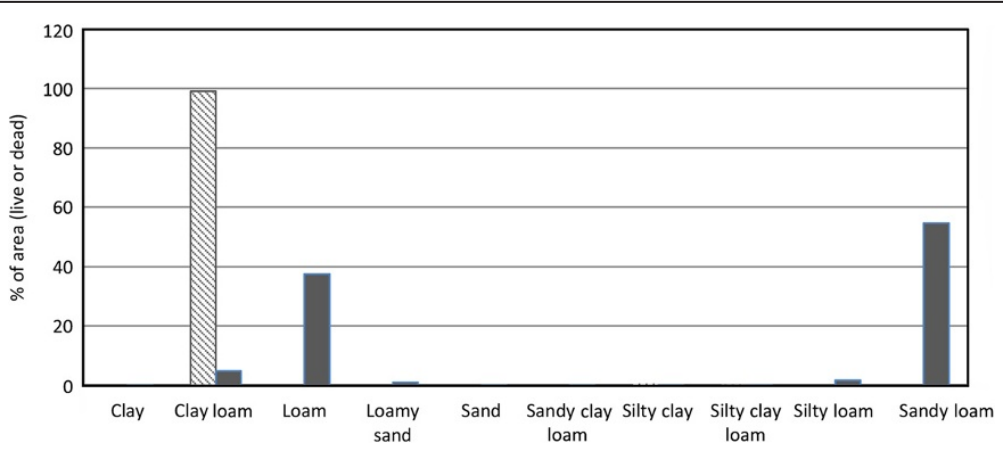

Figure 4 Soil texture and tree mortality in western Montana. This graph shows the percent of the area of tree mortality or tree persistence on each soil texture type for all tree species in all of western Montana, USA between 1998 and 2010. Legend: Striped fill = killed trees, solid fill $=$ live trees. 


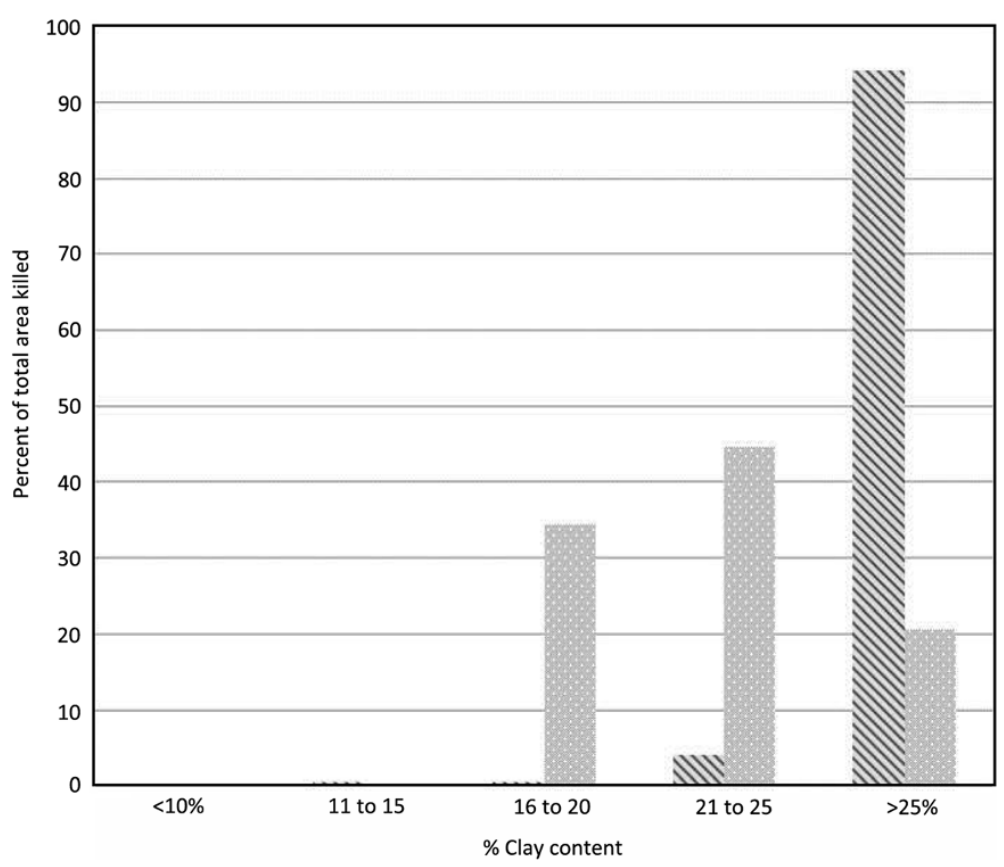

Figure $\mathbf{5}$ Site specific clay content and tree mortality. The graph shows percent clay content of the soil versus the percent of the total area of pines killed on each site. Legend: striped fill = site I mortality, dotted fill = site II mortality.

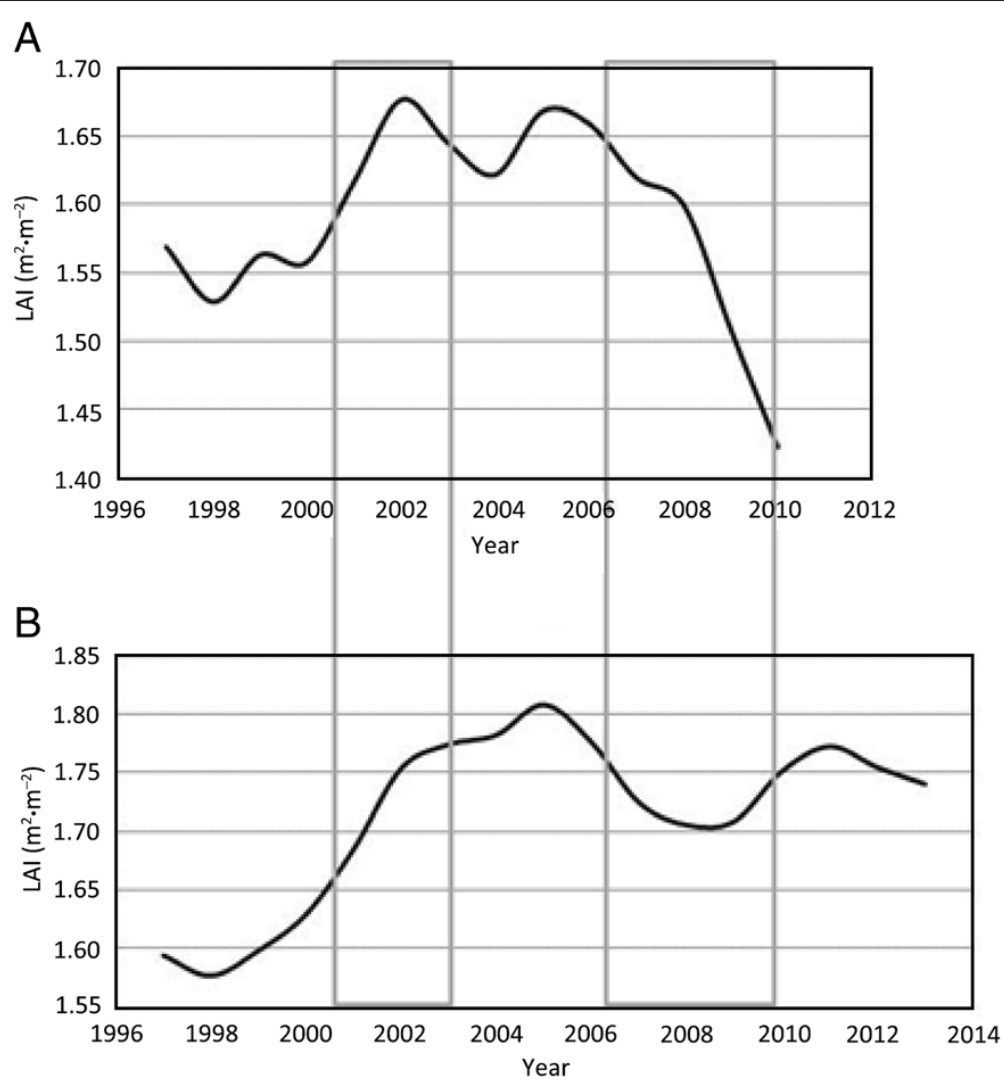

Figure 6 Simulated leaf area index. The graphs show simulated LAl between 1998 and 2010 for site I (A) and site || (B). Gray boxes highlight the periods of high beetle activity on each site. 


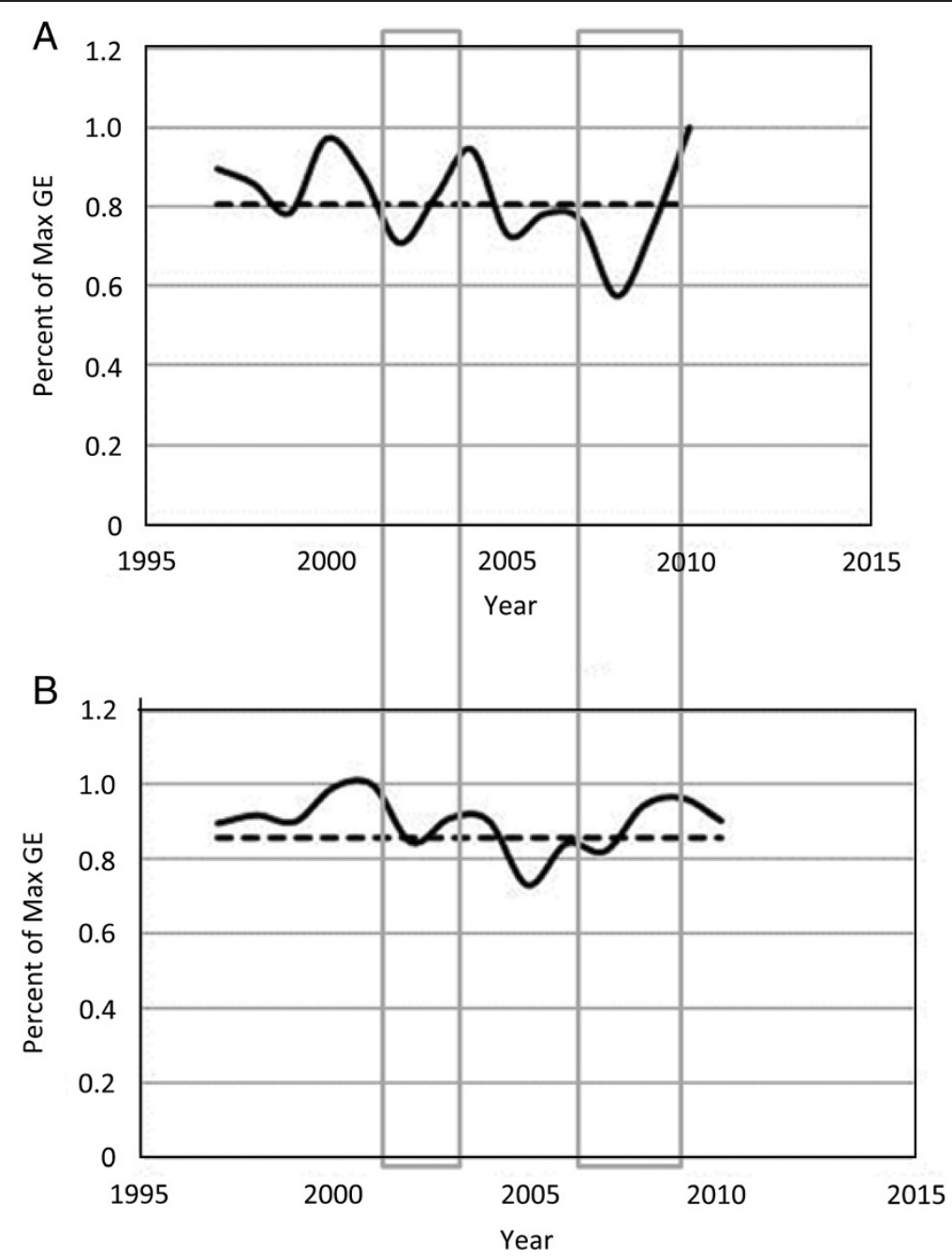

Figure 7 Growth efficiency comparison. The graphs show growth efficiency (GE) normalized over the modeled average for the time period for (A) site I and (B) site II. Gray boxes highlight the time periods of high beetle activity on each site. Legend: solid black lines = annual growth efficiency, dashed black lines = average growth efficiency for the entire time period.

characteristics from their originally mapped condition (USDA NRCS, Soil Survey Division Staff 1993). Therefore, it is imperative to make detailed measurements on specific plots for field research studies and monitoring programs.

There are also considerations when using climate data. As with soil data, the area represented by a given weather station is also subject to spatial variation due to changes in local topography. Equipment from meteorological stations is subject to malfunction and operational differences that bias measurements (NCAR 2014). For example, intense rainfall and strong winds can affect the amount of precipitation measured in collectors. Comparing monthly values with nearby stations to check for correlations can help to adjust for errors and missing values.

Remote sensing satellites are limited by spatial, temporal and spectral resolutions, dynamic range and interference by clouds, snow or aerosols. Remote sensing data may not be useful in estimating LAImax for densely-forested regions, because satellite sensors saturate from the high reflectance (Zhao et al. 2010; Waring et al. 2014). Comparing greenness values for several years can help analysts estimate reasonable values for LAImax for model calibration, but disturbances may be difficult to ascertain due to coarse spatial or spectral resolution or cloud interference (Hilker et al. 2009). Atmospheric interference such as cloud cover causes more visible light to be reflected back to the sensor than would be the case if the light reached the surface and was absorbed by vegetation. When this occurs, the difference between the infrared reflectance and the visible red reflectance, used in calculating NDVI, is smaller than it would be if the emitted radiation were intercepting vegetation. This can result in unrealistic values of NDVI and thus calculated LAI. In the event of an equipment malfunction, data may be missing for multiple months (Landsat 2014). 
In addition to awareness of the limitations of data used in modeling, acknowledgment of the limitations of the models themselves is also important. In this exercise, we used the Excel version of 3-PG with climate data from local weather stations, and thus the simulation results only apply locally. New simulations would need to be run to apply this approach to other sites with appropriate soil and climate values. In addition, 3-PG is run on a monthly time-step, so it estimates general trends in annual carbon, energy and water balances, and it does not have specific algorithms to incorporate the effects of snowmelt dynamics on tree physiology. There is a general assumption that precipitation falling on days with temperatures below -2 ? C is received as snow (Waring et al. 2014). Although 3-PG has some subroutines to simulate the effects of disease on forest productivity, it does not simulate the population dynamics of beetles or their responses to climate change.

\section{Conclusions}

GIS analysis of where tree mortality and bark beetle infestations occurred in western Montana showed that approximately $94 \%$ of the mortality area on site I and $65 \%$ of the mortality area on site II co-occurred with high clay soils ( $>20 \%$ clay content). Sensitivity analysis in the 3-PG model showed that the effect of soil clay content on photosynthesis was more pronounced during drier years. Simulations also showed there may have been an effect of large interannual variations in precipitation, causing an imbalance between leaf area and stem growth, with negative impacts on tree vigor. The combination of water stress and reduced tree vigor could have made the trees more vulnerable to beetles and their associated fungi.

Outbreaks of native insects and diseases are expected to occur in response to future warming temperatures and a drier environment, but tree mortality is not likely to be uniformly distributed across the landscape. Forest managers and policy makers can benefit from methods to help identify where forests are most susceptible to disturbance, so they might ameliorate conditions where and when it will do the most good. Retrospective analyses as performed in this modeling exercise suggest that two specific site variables would be most useful to map in predicting ponderosa pine disturbances: inter-annual variations in canopy leaf area index and soil texture.

\section{Additional file}

Additional file 1: Contains graphs and model output not presented in the main paper, used in 3-PG model calibration and sensitivity analysis for this study.

\section{Abbreviations}

LAl: Leaf Area Index; GE: Growth Efficiency (ratio of Leaf Area Index to Stem Growth); ASW: Available Soil Water Storage Capacity; 3-PG: Physiological
Principles Predicting Growth model; USDA: United States Department of Agriculture; STATSGO: National soil database; FIA: Forest Inventory Analysis Program; NCAR: National Center for Atmospheric Research; NOAA: National Oceanic and Atmospheric Administration; MT: Montana; SSURGO: Soil Survey Geographic Database; NRCS: Natural Resource Conservation Service; NDVI: Normalized Difference Vegetation Index; FR: Soil Fertility; GPP: Gross Primary Productivity; NLCD: National Land Cover Dataset.

\section{Competing interests}

The authors declare that they have no competing interests.

\section{Authors contributions}

WP performed 3-PG modeling and sensitivity analyses, all GIS analyses, climate correlations, remote sensing data analyses and data preparation. RW provided text, interpretation and expert supervision of all analyses. Both authors read and approved the final manuscript.

\section{Acknowledgments}

We would like to thank Thomas Hilker (Oregon State University), Paul Adams (Oregon State University), Ron Reuter (Oregon State University), and Dominique Bachelet (Conservation Biology Institute) for their careful and insightful editing and feedback in writing this article. We thank Brendan Ward (Conservation Biology Insitute) for the use of his Python script to help extract and aggregate soil map units and their attributes from the NRCS soil survey maps.

\section{Author details}

${ }^{1}$ Conservation Biology Institute, 136 SW Washington Ave, Ste 202, Corvallis, OR 97333, USA. ²Department of Forest Ecosystems and Society, Oregon State University, 321 Richardson Hall, Corvallis, OR 97331, USA.

Received: 19 June 2014 Accepted: 8 December 2014

\section{.}

\section{References}

Allen CD, Macalady AK, Chenchouni H, Bachelet D, McDowell N, Vennetier M, Kitzberger T, Rigling A, Breshears DD, Hogg EH, Gonzalez P, Fensham R, Zhang Z, Castro J, Demidova N, Lim J-H, Allard G, Running SW, Semerci A Cobb N (2010) A global overview of drought and heat-induced tree mortality reveals emerging climate change risks for forests. Forest Ecol Manag 259:660 684

Bentz BJ, Regniere J, Fettig CJ, Hansen EM, Hayes JL, Hicke JA, Kelsey RG, Negron JF, Seybold SJ (2009) Bark beetle outbreaks in Western North America: causes and consequences. Bioscience 60:602 613

Berg EE, Henry JD, Fastie CL, DeVolder AD, Matsuoka SM (2006) Spruce beetle outbreaks on the Kenai Peninsula, Alaska, and Kluane National Park and Reserve, Yukon Territory: Relationship to summer temperatures and regional differences in disturbance regimes. Forest Ecol Manag 227:219 232

Bigler C, Br?ker OU, Bugmann H, Dobbertin M, Rigling A (2006) Drought as an inciting mortality factor in Scots pine stands of the Valais, Switzerland. Ecosystems 9:330 343

Brasier CM (1996) Phytophthera cinnamomi and oak decline in southern Europe. Environmental constraints including climate change. Ann For Sci 53:347 358

Briffa KR, Bartholin JS, Eckstein D, Jones PD, Karl?n W, Schweingruber FH, Zetterberg P (1990) A 1,400-year tree-ring record of summer temperatures in Fennoscandia. Nature 346:434 439

Bryant JP, Julkunen-Tiitto R (1995) Ontogenic development of chemical defense by seedling resin birch: Energy cost of defense production. J Chem Ecol 21:883 896

Christiansen E (1985) Ips/Ceratocystis infection of Norway spruce: what is a lethal dosage? Z Angew Entomol 99:6 11

Christiansen E, Waring RH, Berryman AA (1987) Resistance of conifers to bark beetle attack: Search for general relationships. For Ecol Manag 22:89 106

Coops NC, Waring RH, Moncrieff J (2000) Estimating mean monthly incident solar radiation on horizontal and inclined slopes from mean monthly temperature extremes. J Biometeorol 44:204 211

Coops NC, Waring RH, Wulder MA, White JC (2009) Prediction and assessment of bark beetle-induced mortality of lodgepole pine using estimates of stand vigor derived from remotely sensed data. Remote Sens Environ 12:1058 1066

Covington WW, Moore MM (1994) Postsettlement changes in natural fire regime and forest structure: ecololigical restoration of old-growth ponderosa pine forests. J Sustain Forestry 2:153 181 
Dale VH, Joyce JA, McNulty S, Neilson RP, Ayres MP, Flannagan MD, Hanson PJ, Irland LC, Lugo AE, Peterson CJ, Simberloff D, Swanson FJ, Stocks BJ, Wotton BM (2001) Climate change and forest disturbances. Bioscience 51:723 734

DeBlander LT (2002) Forest resources of the Lewis and Clark National Forest. USDA Forest Service Rocky Mountain Research Station. Ogden, Utah

Erbilgin N, Powell J, Raffa K (2003) Effect of varying monoterpene concentrations on the response of Ips pini (Coleoptera: Scolytidae) to its aggregation pheromone: implications for pest management and ecology of bark beetles. Agr For Entomol 5:269 274

Fettig CJ, Klepsig KD, Billings RF, Munson AS, Nebeker TE, Negron JF, Nowak JT (2007) The effectiveness of vegetation management practices for prevention and control of bark beetle infestations in coniferous forests of the western and southern United States. For Ecol Manag 238:24 53

Franceschi VR, Krokene P, Christiansen E, Krekling T (2005) Anatomical and chemical defenses of conifer bark against bark beetles and other pests. New Phytol 167:353 375

Franklin JF, Dyrness CT (1969) Vegetation of Oregon and Washington. USDA Forest Service, Research Paper PNW-80. Pacific Northwest Forest and Range Experiment Station, Portland, OR

Fry J, Xian G, Jin S, Dewitz J, Homer C, Yang L, Barnes C, Herold N, Wickham J (2011) Completion of the 2006 National Land Cover Database for the Conterminous United States. PE\&RS 77:858 864

Garfinkel HL, Brubaker LB (1980) Modern climate-tree growth relationships and climatic reconstruction in subarctic Alaska. Nature 286:872 874

Hacke UG, Sperry JS, Ewers BE, Ellsworth DS, Schaefer KVR, Oren R (2000) Influence of soil porosity on water use in Pinus taeda. Oecologia 124:495 505

Harper RJ, Smettem KRJ, Carter JO, McGrath JF (2009) Drought deaths in Eucalyptus globulus (Labill.) plantations in relation to soils, geomorphology and climate. Plant Soil 324:199 207

Heidmann LJ, King RM (1992) Effect of prolonged drought on water relations of ponderosa pine seedlings grown in basalt and sedimentary soils. USDA For Serv Res Paper RM-301. Rocky Mountain Forest and Range Experiment Station, Fort Collins, CO

Hilker T, Coops NC, Coggins SB, Wulder MA, Brown M, Black TA, Nesic Z, Lessarde D (2009) Detection of foliage conditions and disturbance from multi-angular high spectral resolution remote sensing. Remote Sens Environ 113:421 434

Hoffman GR, Alexander RR (1976) Forest vegetation of the Big Horn Mountains, Wyoming, a habitat type classification. USDA Forest Service, Research Paper RM-170. Rocky Mountain Forest and Range Experiment Station, Fort Collins, CO

Hogg EH, Brandt JP, Michaelian M (2008) Impacts of a regional drought on the productivity, dieback and biomass of western Canadian aspen forests. Can J Forest Res 38(6):1373 1384

Horntvedt R, Christiansen E, Solheim H, Wang S (1983) Artificial inoculation with Ips typographus-associated blue-stain fungi can kill healthy Norway spruce trees. Medd Nor Inst Skogforsk 38:1 20

Huber DPW, Ralph S, Bohlmann J (2004) Genomic hardwiring and phenotypic plasticity of terpenoid-based defenses in conifers. J Chem Ecol 30:2399 2418

Landsat (2014) Landsat Missions., http://landsat.usgs.gov/. Accessed 1 May 2014

Landsberg JJ, Waring RH (1997) A generalized model of forest productivity using simplified concepts of radiation-use efficiency, carbon balance and partitioning. For Ecol Manag 95:209 228

Larsson S, Oren R, Waring RH, Barrett JW (1983) Attacks of mountain pine beetle as related to tree vigor of ponderosa pine. Forest Sci 29:395 402

Meddens AJH, Hicke JA, Ferguson CA (2012) Spatial and temporal patterns of observed bark beetle-caused tree mortality in British Columbia and the western. US Ecol Appl 22:1876 1891

Nambiar EKS, Sands R (1992) Effects of compaction and simulated root channels in the subsoil on root development, water uptake and growth of radiate pine. Tree Physiol 10:297 306

NCAR (2014) Climate Data Guide., https://climatedataguide.ucar.edu/. Accessed 1 May 2014

Negr?n JF, Popp JB (2004) Probability of ponderosa pine infestation by mountain pine beetle in the Colorado Front Range. For Ecol Manag 191:17 27

NOAA (2013) National Climate Data Center: Climate Data Online., http://www. ncdc.noaa.gov/cdo-web/. Accessed 14 January 2014

NRCS (2014) Web Soil Survey., http://websoilsurvey.sc.egov.usda.gov/App/ WebSoilSurvey.aspx. Accessed 21 January 2014

Panek JA, Waring RH (1997) Stable carbon isotopes as indicators of limitation to forest growth imposed by climate stress. Ecol Appl 7:854 863

Pook EW (1984) Canopy dynamics of Eucalyptus maculata Hook. II. Canopy leaf area balance. Aust J Bot 32:405 413
Powers RF, Scott DA, Sanchez FG, Voldseth RA, Page-Dumroese D, Elioff JD, Stone DM (2005) The North American long-term soil productivity experiment: Findings from the first decade of research. For Ecol Manag 220:31 50

Puhlick JJ, Laughlin DC, Moore MM (2012) Factors influencing Ponderosa Pine regeneration in the Southwestern USA. For Ecol Manag 264:10 19

Raffa KF, Aukema BH, Bentz BJ, Carroll AL, Hicke JA, Turner MG, Romme WH (2008) Cross-scale drivers of natural disturbances prone to anthropogenic amplification: the dynamics of bark beetle eruptions. Bioscience 58:501 517

Rouault G, Candau J-N, Lieutier F, Nageleisen L-M, Martin J-C, Warz?e N (2006) Effects of drought and heat on forest insect populations in relation to the 2003 drought in western Europe. Ann Forest Sci 63:613 624

Runyon J, Waring RH, Goward SN, Welles JM (1994) Environmental limits on net primary production and light-use efficiency across the Oregon transect. Ecol Appl 4:226 237

Samuelson LJ, Johnsen K, Stokes T (2004) Production, allocation and stemwood growth efficiency of Pinus taeda L. stands in response to 6 years of intensive management. For Ecol Manag 192(1):59 70

Schmid JM, Mata SA (1992) Stand density and mountain pine beetle-cause tree mortality in ponderosa pine stands. RN-RM-515. U.S. Department of Agriculture, Forest Service, Rocky Mountain Forest and Range Experiment Station, For Collins, CO

Schmid JM, Mata SA (2005) Mountain pine beetle-caused tree mortality in partially cut plots surrounded by unmanaged stands. RP-RMRS-54. U.S. Department of Agriculture, Forest Service, Rocky Mountain Research Station, Fort Collins, CO

Scianna J (2011) Ponderosa pine. USDA NRCS Plant Materials Technical Note, MT-73

Sperry JS, Hacke UG, Oren R, Comstock JP (2002) Water deficits and hydraulic limits to leaf water supply. Plant Cell Environ 25:251 263

Turner J, Lambert M (2005) Soil and nutrient processes related to eucalypt forest dieback. Austral For 68:251 256

Turner DP, Cohen WB, Kennedy RE, Fassnacht KS, Briggs JM (1999) Relationships between Leaf Area Index and Landsat TM Spectral Vegetation Indices across Three Temperate Zone Sites. Remote Sens Environ 70(1):52 68

USDA NRCS, Soil Survey Division Staff (1993) Soil Survey Manual. Soil Conservation Service. U.S. Department of Agriculture Handbook 18

USDA NRCS, Soil Survey Division Staff (1995) Soil Survey Geographic (SSURGO) Data Base: Data Use Information. US Department of Agriculture Miscellaneous Publication Number 1527

USFS FHTET (2010) USDA Forest Service, Forest Health Protection, Forest Health Technology Enterprise Team, data

USGS (2014) USGS Global Visualization Viewer., http://glovis.usgs.gov/. Accessed 23 January 2014

Viereck LA, Dyrness CT, Van Cleve K, Foote MJ (1983) Vegetation, soils, and forest productivity in selected forest types in interior Alaska. Can J For Res 13:703 720

Villalba R (1990) Tree-ring and glacial evidence for the Medieval warm epoch and the little ice in southern South America. Clim Change 26:183 197

Wallin KF, Raffa KF (2000) Influences of external chemical cues and internal physiological parameters on the multiple steps of post-landing host election behavior of Ipspini (Coleoptera: Scholytidae). Environ Entomol 29:442 453

Wallin KF, Raffa KF (2004) Feedback between individual host selection behavior and population dynamics in an eruptive insect herbivore. Ecol Monogr 74:101 116

Waring RH (1983) Estimating forest growth and efficiency in relation to canopy leaf area. Adv Ecol Res 13:327 354

Waring RH, Pitman GB (1983) Physiological stress in lodgepole pine as a precursor for mountain pine beetle attack. J Appl Entomol 1:265 270

Waring RH, Coops NC, Running SW (2011) Predicting satellite-derived patterns of large-scale disturbances in forests of the Pacific Northwest region in response to recent climatic variation. Remote Sens Environ 115:3554 3566

Waring RH, Coops NC, Mathys A, Hilker T, Latta G (2014) Process-based modeling to assess the effects of recent climatic variation on site productivity and forest function across Western North America. Forests 5:518 534

Wright LC, Berryman AA, Gurusiddaiah S (1979) Host resistance to the fir engraver beetle, Solytusventralis (Coleoptera: scolytidae): 4. Effect of defoliation on wound monotermpene and inner bark carbohydrate concentrations. Can Entomol 111:1255 1262

Wright LC, Berryman AA, Wickman BE (1984) Abundance of the fir engraver, Scolytusventralis, and the Douglas-fir beetle, Dentroctonus pseudostugae, following tree defoliation by the Douglas-fir tussock moth, Orgyia pseudstugata. Can Entomol 116:293 305

Wu C, Chen JM (2013) Diverse responses of vegetation production to interannual summer drought in North America. Int J Appl Earth Obs 21:1 6 
Xu XN, Wang Q, Shibata H (2008) Forest structure, productivity and soil properties in a subtropical evergreen broad-leaved forest in Okinawa, Japan J Forest Res 19:271 276

Yoshiko A, Mueller-Dombois D (1995) A landscape perspective of the Hawaiian rain forest dieback. J Veg Sci 6:449 464

Zausen GL, Kolb TE, Bailey JD, Wagner MR (2005) Long-term impacts of stand management on ponderosa pine physiology and bark beetle abundance in northern Arizona: A replicated landscape study. For Ecol Manag 218:291 305

Zhao J, Liu JL, Yang L (2010) A preliminary study on mechanisms of LAl inversion saturation. Int Arc Photogram Remote Sens Spatial Inf Sci XXXIX-B1:77 81

doi:10.1186/s40663-014-0024-1

Cite this article as: Peterman and Waring: Does overshoot in leaf development of ponderosa pine in wet years leads to bark beetle outbreaks on fine-textured soils in drier years? Forest Ecosystems 2014 1:24,

\section{Submit your manuscript to a SpringerOpen ${ }^{\circ}$} journal and bene $\otimes t$ from:

- Convenient online submission

- Rigorous peer review

- Immediate publication on acceptance

- Open access: articles freely available online

- High visibility within the \eld

- Retaining the copyright to your article 